\title{
HUKUMAN MATI BAGI PENGEDAR NARKOBA DALAM PERSPEKTIF HUKUM ISLAM
}

\section{Zainuddin Abdullah}

STIT Al-Amin Kreo Tangerang

zainuddinmh@gmail.com

\begin{abstract}
:
In the early of Islam, the meaning of khamr is kind of intoxicating drinks that they are made from grape, dates, wheat and so on. The meaning of khamr experiences development either from kind, name and its danger that follows the development of time. In Islamic law, for the dealer of Narkoba with certain scale can be categorized as criminal act (Hirābah), extraordinary crime and because of that threatened with Hudüd sentence such as death sentence. It suits the spirit of Maqūsid al-Syarīah especially about al-Darüriyyah al-Khams.
\end{abstract}

Keywords: Death Sentence, Criminal Act, The Objective of Islamic Law. 


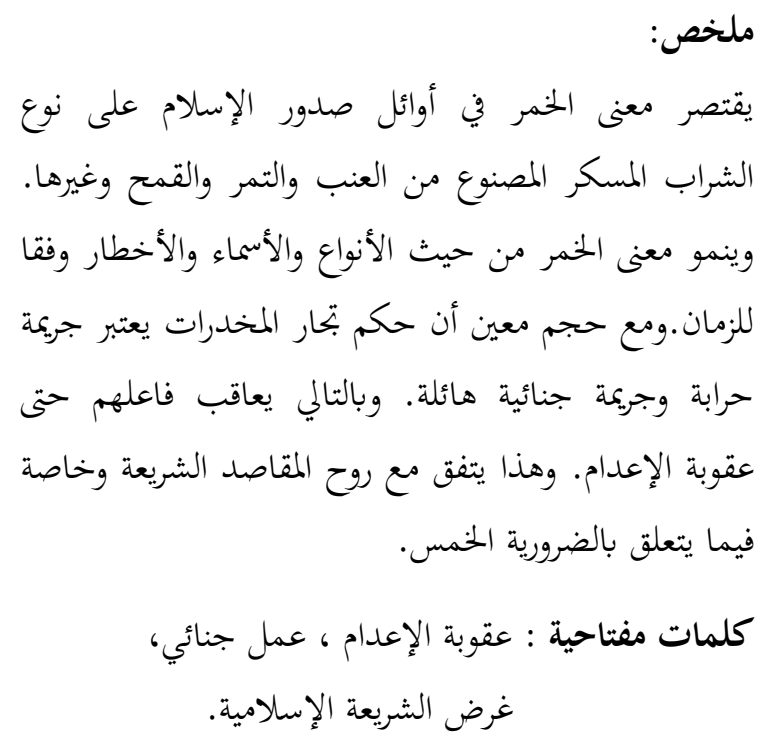

\section{A. Latar Belakang Masalah}

Penyalahgunaan narkoba (narkotika, obat/bahan adiktif lain yang berbahaya) atau napza (narkotika, psikotropika, zat adiktif) merupakan permasalahan yang sangat serius dihadapi oleh hampir seluruh negara di dunia termasuk Indonesia. Akhir-akhir ini, permasalahan tersebut semakin marak dan meluas secara sporadis dan terbukti dengan meningkatnya jumlah penyalahgunaan, pengedar yang tertangkap dan pabrik ilegal narkotika yang dibangun di Indonesia.

Penyalahgunaan narkoba di luar kepentingan pelayanan kesehatan atau untuk pengembangan ilmu pengetahuan adalah perbuatan melawan hukum, mengingat pemakaian secara ilegal. Di samping melanggar hukum juga sangat membahayakan keselamatan jiwa manusia. Dalam upaya pemberantasan peredaran gelap narkoba yang termasuk kejahatan transnasional dan terorganisir, pemerintah melalui aparat keamanan dan penegak hukum telah banyak melakukan penangkapan, penggerebekan, serta pemberian hukuman. 


\section{Zainuddin Abdullah}

Di Indonesia dan berbagai belahan dunia lainnya, narkoba (narkotika dan obat-obatan berbahaya) telah mempengaruhi segala lapisan masyarakat, terutama generasi muda. Konsumsi terhadap narkoba semakin banyak di kalangan remaja, yang dianggap sebagai salah satu cara untuk menghilangkan stress, konflik dan berbagai problem yang mereka hadapi. Keberadaan narkoba mengancam hari depan manusia, di samping penyakit ganas, dari waktu ke waktu narkotika mengalami peningkatan, baik dari aspek kualitas maupun kuantitasnya.

Seiring dengan berjalannya waktu, penyalahgunaan narkoba di tanah air terus menerus meningkat pesat dengan skala yang sangat mengerikan. Fakta menunjukkan bahwa yang mengedarkan dan mengkonsumsi narkoba sedemikian masif dan sporadis dilakukan oleh hampir semua lapisan masyarakat, mulai dari masyarakat luas khususnya generasi muda hingga para elite politik, anggota legislatif, pejabat pemerintah, aparat pemerintah, serta aparat keamanan dan penegak hukum itu sendiri.

Jika kondisi ini terus berjalan maka diduga kuat kehancuran dalam berbagai sendi kehidupan akan terjadi, baik di bidang politik, ekonomi, moral, sosial, keamanan, maupun sendi kehidupan lainnya. Dan jika fenomena ini terjadi maka tinggal menunggu waktu saja kehancurannya bangsa ini.

Kekhawatiran dan kengerian ini tentu harus disikapi dengan bijak, cermat, komprehensif, dan padu dengan berbagai pendekatan. Salah satu pendekatan yang sangat memungkinkan adalah penegakan hukum yang tegas oleh para penegak hukum (pemerintah) bagi semua pelaku.

Tampaknya pemerintah mulai menyikapi hal ini dengan sungguh-sungguh. Diantara yang dilakukannya adalah dengan melakukan hukuman mati bagi pengedar narkoba dengan spesifikasi tertentu. Persoalannya adalah sikap pemerintah tersebut ternyata mengundang reaksi beragam di tengah-tengah masyarakat antara setuju dan tidak setuju.

Pada masalah ini penulis mencoba melihat bagaimana kedudukan hukuman mati bagi pengedar narkoba dalam perspektif hukum Islam dengan tinjauan metode istinbāt tafsir ayat ahkām.

\section{B. Pembahasan}




\section{Pengertian Narkoba}

Kata 'Narkoba' merupakan singkatan dari kata narkotika, psikotropika, dan bahan adiktif. Secara etimologis kata narkoba berasal dari bahasa Inggris Nacose atau narcosis yang berarti menidurkan atau pembiusan. Secara terminologi dalam Kamus Besar Bahasa Indonesia, narkoba atau narkotika adalah obat yang dapat menenangkan syarat, menghilangkan rasa sakit, menimbulkan ngantuk atau merangsang. ${ }^{1}$ Sedangkan secara terminologi narkoba diartikan:

a. Narkotika adalah zat atau obat yang berasal dari tanaman atau bukan tanaman baik sintesis maupun semi sintesis yang dapat menyebabkan penurunan atau kesadaran, hilangnya rasa nyeri dan dapat menimbulkan ketergantungan.

b. Psikotropika adalah zat atau obat, baik alamiah maupun sintesis bukan narkotika, yang berkhasiat psikoaktif melalui pengaruh selektif pada susunan saraf pusat yang menyebabkan perubahan khas pada aktivitas mental dan pelaku.

c. Bahan adiktif lainnya adalah bahan lain bukan narkotika atau psikotropika yang penggunaannya dapat menimbulkan ketergantungan. ${ }^{2}$

Pengertian yang lainnya juga disebutkan bahwa narkoba adalah obat, bahan atau zat bukan makanan, yang jika masuk ke dalam tubuh manusia, berpengaruh terutama pada kerja otak (susunan saraf pusat). ${ }^{3}$

Dalam surat edaran BNN No. CE/03/IV/2002 disebutkan juga bahwa narkotika yaitu zat-zat alami maupun kimiawi yang jika dimasukkan ke dalam tubuh

1 Zainudin Ali, Hukum Pidana Islam, (Jakarta: Sinar Grafika, 2007), cet. I, h. 101.

2 Dirumuskan oleh tim kerja BNN, Mabes Polri, Depdagri dan BKKBN, Pedoman Pelaksanaan P4GN/Melalui Pesan serta Kepala Desa/Lurah Babinkamtibnas dan PLKB di tingkat Desa/Kelurahan, (Jakarta: Badan Narkotika Nasional, 2007), h. 43.

3 Tim Perumus dari BNN RI, Modul untuk Orang Tua Mencegah Lebih Baik daripada Mengobati, (Jakarta: Badan Narkotika Nasional, 2007), h. 54.

142| Al Amin:Jurnal Kajian Ilmu dan Budaya Islam, Volume 1, No 2, 2018 


\section{Zainuddin Abdullah}

dapat mengubah pikiran, suasana hati, perasaan dan perilaku seseorang. ${ }^{4}$

Dari beberapa pengertian di atas dapat penulis simpulkan bahwa narkoba adalah zat yang dapat membahayakan tubuh terutama fungsi agar pusat (otak) bagi penggunanya yang juga mengubah pikiran, perasaan dan perilaku seseorang serta mengakibatkan ketergantungan bagi pemakainya.

\section{Penggolongan Narkoba}

a. Narkotika

1) Narkotika golongan I: berpotensi sangat tinggi menyebabkan ketergantungan baik digunakan untuk terapi pengobatan. Contoh: heroin, kokain, dan ganja. Putauw adalah heroin tidak murni berupa bubuk.

2) Narkotika golongan II: berpotensi tinggi menyebabkan ketergantungan. Digunakan pada terapi sebagai pilihan terakhir. Contoh: morfin, petidin, dan matadon.

3) Narkotika golongan III: berpotensi ringan menyebabkan ketergantungan dan banyak digunakan dalam terapi. Contoh: kodein. ${ }^{5}$

b. Psikotropika

1) Psikotropika golongan I: amat kuat menyebabkan ketergantungan dan tidak digunakan dalam terapi. Contoh: MDMA (ekstasi), LSD dan STP.

2) Psikotropika golongan II: Kuat menyebabkan ketegantungan, digunakan amat terbatas pada terapi. Contoh: amfetamin, metafetamin (shabu), fensiklidin dan ritalin.

3) Psikotropika golongan III: Potensi sedang, menyebabkan ketergantungan, banyak dipergunakan dalam terapi. Contoh: rentobarbital dan flunitrazepam.

4) Psikotropika golongan IV: potensi ringan menyebabkan ketergantungan dan sangat luas digunakan dalam terapi. Contoh: diazepam, klobozam, fenobartbital, barbital, klozepam,

4 Tim Perumus dari BNN RI, Mengenal Penyalahgunaan Narkoba, (Jakarta: Badan Narkotika, Nasional, 2007), h. 8.

5 Dirumuskan oleh Tim Kerja BNN, Mabes Polri, h. 44-45. 
klordiazepoxide dan nitrazepam (nipam, pil KB/Koplo, DUM, MG, Lexo, rohyp, dll)

c. Bahan adiktif lainnya yang sering disalahgunakan:

1) Alkohol, yang terdapat pada berbagai jenis minuman keras.

2) Inhalansia/solven, yaitu gas atau zat yang mudah menguap yang terdapat pada kebutuhan pabrik, kantor dan rumah tangga. ${ }^{6}$

d. Bahan aktif lain tergolong legal/tidak melanggar 105 amper antara lain:

1) Nikotin yang terdapat pada tembakau.

2) Kafein pada kopi, teh minuman penyebar dan beberapa jenis obat.

3) Alkohol, pada minuman yang mengandung alkohol.

4) Bahan pelarut bagi keperluan rumah tangga, industri dan kantor, seperti lem, thiner dan bensin yang disebut solven/inhalansia. ${ }^{7}$

\section{Penggolongan Bahaya Narkoba Berdasarkan Jenisnya adalah:}

a. Opoid: depresi berat, rasa lelah berlebihan, banyak tidur, gugup, gelisah, denyut jantung bertambah cepat, rasa gembira berlebihan, banyak bicara namun cadel, rasa harga diri meningkat, kejang-kejang, tekanan darah meningkat, berkeringat dingin, mual hingga muntah, luka pada sekat rongga hidung, kehilangan nafsu makan dan turunnya berat badan.

b. Ganja: kantong mata terlihat bengkak, merah dan berair, sering melamun, pendengaran terganggu, selalu tertawa, terkadang cepat marah, tidak bergairah, gelisah, dehidrasi, tulang gigi keropos, liver, saraf otak dan saraf mata rusak dan skizofrenia.

c. Esktasi: energik tetapi matanya sayu dan wajahnya pucat, berkeringat, sulit tidur, kerusakan saraf otak, dehidrasi, gangguan liver, tulang dan gigi keropos, tidak ada nafsu makan, dan saraf mata rusak.

d. Shabu-shabu: energik, paranoid, sulit tidur, sulit berpikir, kerusakan saraf otak terutama saraf

6 Dirumuskan oleh Tim Kerja BNN, Mabes Polri, h. 46-47.

7 Tim Perumus BNN, Modul untuk Orang Tua, h. 5. 


\section{Zainuddin Abdullah}

pengendali pernapasan sehingga merasa sesak napas, banyak bicara, denyut jantung bertambah cepat, pendarahan otak, shock pada pembuluh darah dan jantung yang akan berujung pada kematian. ${ }^{8}$

\section{Dampak Penyalahgunaan Narkotika}

Bila narkotika digunakan secara terus menerus atau melebihi takaran yang telah ditentukan akan mengakibatkan ketergantungan. Ketergantungan atau kecanduan inilah yang akan mengakibatkan gangguan fisik dan psikologis, karena terjadinya kerusakan pada Sistem Saraf Pusat (SSP) dan organ-organ tubuh seperti jantung, paru-paru, hati dan ginjal.

Dampak penyalahgunaan narkotika pada seseorang sangat tergantung pada jenis narkotika yang dipakai, kepribadian pemakai dan situasi atau kondisi pemakai. Secara umum, dampak kecanduan narkotika dapat terlihat pada fisik, psikis maupun sosial seseorang.

a. Dampak Fisik Penyalahgunaan Narkoba

1) Gangguan pada saraf-saraf (neurologis) seperti kejang-kejang, halusinasi, gangguan kesadaran, kerusakan saraf tepi.

2) Gangguan pada jantung dan pembuluh darah (kardiovaskuler) seperti infeksi akut otot jantung, gangguan peredaran darah.

3) Gangguan pada kulit (dermatologis) seperti penanahan (abses), alergi, eksim.

4) Gangguan pada paru-paru (pulmoner) seperti penekanan fungsi pernapasan, kesukaran bernafas, pengerasan jaringan paru-paru.

5) Sering sakit kepala, mual-mual dan muntah, suhu tubuh meningkat, pengecilan hati dan sulit tidur.

6) Dampak terhadap kesehatan reproduksi adalah gangguan pada endokrin seperti penurunan fungsi hormone reproduksi (estrogen, progesterone, testosteron), serta gangguan fungsi seksual.

7) Dampak terhadap kesehatan reproduksi pada remaja perempuan antara lain perubahan periode

8 Ibrahimstwo@gmail.com, Makalah: Bahaya Narkoba bagi Remaja. 
menstruasi, ketidakteraturan menstruasi dan amenorhoe (tidak haid).

8) Bagi pengguna narkoba melalui jarum suntik, khususnya pemakai jarum suntik secara bergantian, risikonya adalah tertular penyakit seperti hepatitis B, C dan HIV yang hingga saat ini belum ada obatnya.

9) Penyalahgunaan narkoba bisa berakibat fatal ketika terjadi over dosis yaitu konsumsi narkoba melebihi kemampuan tubuh untuk menerimanya. Over dosis bisa menyebabkan kematian.

b. Dampak Psikis Penyalahgunaan Narkoba

1) Malas belajar, ceroboh, sering tegang dan gelisah.

2) Hilang kepercayaan diri, apatis, pengkhayal, penuh curiga.

3) Agitatif, menjadi ganas dan tingkah laku yang brutal.

4) Sulit berkonsentrasi, perasaan kesal dan tertekan.

5) Cenderung menyakiti diri, perasaan tidak aman, bahkan bunuh diri. 9

\section{Dampak Narkoba Terhadap Kesehatan}

Salah satu jenis narkoba adalah minuman yang memabukkan atau yang disebut khamar. Khamar mengandung zat kimia alkohol yang akan merusakan kesehatan manusia, dalam hal ini berbagai hasil penelitian menemukan bahwa semakin tinggi kandungan kadar alkohol atau minuman yang memabukkan, maka semakin tinggi pula pengaruhnya terhadap kesehatan. Sebaliknya meskipun minuman memabukkan mempunyai kadar alkohol rendah tetapi jika dikonsumsi secara terus menerus sampai jumlah besar yang beredar dalam tubuh, maka berakibat mempengaruhi kesehatan manusia. Sebagaimana yang dikemukakan oleh Ahmad Syauqi al-Fanjari sebagai berikut: 'Jika seseorang meminum minuman memabukkan dua gelas air, maka 146 amper yang masuk ke dalam darahnya sebesar 5 mgr pada setiap $100 \mathrm{~cm}$ darah. Kemudian ke dalam darah, orang itu

9 Deputi Bidang Pencegahan Badan Narkotika Nasional Republik Indonesia, Mahasiswa dan Bahaya Narkotika, (Jakarta: BNNRI, 2012), h. 14-15.

146| Al Amin:Jurnal Kajian Ilmu dan Budaya Islam, Volume 1, No 2, 2018 


\section{Zainuddin Abdullah}

tentu akan kehilangan daya tahan fisik dan akan kehilangan daya tahan fisik dan akan kehilangan control diri (self control) kenormalan akalnya.'

Ketika mengekspresikan perasaan senang, sedih, menangis, gembira namun ia masih mampu mengendalikan saraf dalam tubuhnya. Pada keadaan ini ia tidak akan pingsan, melainkan hanya sempoyongan ketika berjalan. Apabila kadar alkohol yang masuk ke dalam darah itu bertambah hingga 150 mgr pada setiap $100 \mathrm{~cm}$ darah, ia akan kehilangan kontrol diri, bahkan hilang pula kontrol saraf dalam tubuhnya. Lebih dari itu pada strata ini pusat saraf yang tertinggi menjadi kosong tanpa aktivitas (tidak mampu menerima respons). ${ }^{10}$

\section{Jumlah Korban Narkoba di Indonesia}

Angka prevalensi penyalahgunaan narkoba dari tahun ke tahun mengalami peningkatan bahkan prediksi pada 2015 diperkirakan jumlah pengguna narkoba di Indonesia akan mencapai 5,8 juta jiwa. Hal ini karena jumlah pengguna narkotika untuk saat ini telah mencapai 4 juta jiwa.

Hal ini disampaikan Menteri Hukum dan HAM, Amir Syamsuddin yang disampaikan Direktur TPUL, Jaksa Agung Muda Tingkat Pidana Umum Kejagung RI Ahmad Djainuri, pada sosialisasi Peraturan PerundangUndangan Narkotika.

Ahmad Djainuri juga mengatakan, perkembangan penyalahgunaan dan peredaran gelap narkotika saat ini telah mencapai tingkat yang sangat memprihatinkan. Jumlah pengguna narkotika tercatat saat ini hampir 4 juta jiwa, hasil penelitian yang dilakukan Badan Narkotika Nasional (BNN) dengan Puslitkes UI pada 2011 menunjukkan angka prevalensi penyalahgunaan narkoba dari tahun ke tahun mengalami peningkatan di mana pada tahun 2015 diperkirakan jumlah pengguna narkoba mencapai 5,8 juta jiwa. ${ }^{11}$

\section{Narkoba Dalam Pandangan Syariat Islam}

10 Ahmad Syauqi al-Fanjuri, Nilai Kesehatan Dalam Syariat Islam, (Jakarta: Bumi Aksara, 1999), cet. II, h. 214.

11 http://ww.merdeka.com/peristiwa/pengguna-narkoba-diindonesia-pada-2015-capai-58-juta-jiwa.html, diakses pada hari Selasa pukul 23.00. 
Istilah Narkoba pada awal Islam dikenal, baik dalam al-Qur'an maupun al-Hadits. Yang ditunjukkan dalam al-Qur'an maupun al-Hadits adalah kata khamar.

Berkenaan dengan kata khamar ini, syekh Ali Shalih, al-Bassam mengatakan:

$$
\begin{aligned}
& \text { للخمر في اللغة ثلاث معان: } \\
& \text { 1. الستر والتغطية، ومنه: اختمرت المرأة إذا غطت رأسها ووجهها بالخمار. } \\
& \text { 2. المخالطة، ومنه قول كثير عزة: هنيئا مريعا غير داء مخامر أي مخالط. } \\
& \text { 3. و والادراك، ومنه قولم: خمرت العجين وهو أن تتركه حتى يبلغ وقت ادراكه. } \\
& \text { فمن هذه المعان الثلاثة أخذ اسم الخمرة. لأفها تغطى العقل وتستره ولأنها } \\
& \text { تخالط العقل ولأها تترك حتى تدرك وتستوى. }
\end{aligned}
$$

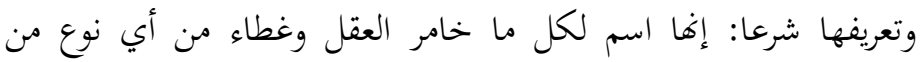

$$
\begin{aligned}
& \text { الأشربة لحديث كل مسكر خمر وكل خمر حرام. }
\end{aligned}
$$

"Khamar secara bahasa mempunyai tiga makna:

1. Tabir dan penutup. Jika dikatakan: 'Ikhtamarat almar'ah, yaitu wanita itu menutupi kepalanya dan wajahnya dengan khimār (kerudung).

2. Bercampur. Diantaranya seperti perkataan yang banyak beredar: 'hanīan marīan ghaira dāin mukhāmirin...' artinya: bercampur.

3. Matang. Diantaranya seperti perkataan mereka: "khamarat al-'ajin: yang artinya: engkau membiarkannya hingga waktu matang. Dari ketiga makna ini, diambillah kata al-khamarah, karena ia menutupi akal, mencampurkannya/mengacaukannya, dan karena dibiarkan baru kemudian sadar dan normal. Adapun definisi secara syar'i, maka ia nama untuk segala macam minuman yang dapat mengacaukan akal dan menutupinya; berdasarkan hadits: segala sesuatu yang memabukkan adalah khamar, dan semua jenis khamar adalah haram. ${ }^{12}$

12 Abdullah bin Abdurrahman bin Shalih Ali Bassam, Tafsīr al-'Álam; Syarh 'Umdah al-Hikam, (Maktabah al-Syamilah), juz 2, h. 159.

148| Al Amin: Jurnal Kajian Ilmu dan Budaya Islam, Volume 1, No 2, 2018 


\section{Zainuddin Abdullah}

Muhammad Ali al-Shabuni dalam Tafsīr Āyāt Ahkām menyatakan bahwa khamar adalah sesuatu yang memabukkan yang dihasilkan dari perasan anggur dan sebagainya. Kata Khamar terambil dari khamara alsyai 'a iża satarahu wa ghatțāhu (menutupi sesuatu yaitu apabila sesuatu itu tertutup). Dia itu dinamakan khamar karena menutupi akal. ${ }^{13}$ Adapun mengenai apakah khamar itu merupakan segala sesuatu yang memabukkan, Ali al-Shabuni menyatakan bahwa Abu Hanifah memahami bahwa khamar adalah minuman yang memabukkan yang dibuat dari perasan anggur. Adapun minuman lain yang memabukkan terbuat dari selainnya seperti dari kurma atau gandum maka dinamakan nab̈z ini adalah pendapat mazhab ulama Kuffi, al-Nakha i, al-Tsauri dan Abu Laili. Sementara itu jumhur fuqahä (Malik, Syafi'i, dan Ahmad) berpendapat bahwa khamar adalah satu nama untuk minuman yang memabukkan baik dari perasan anggur, kurma, gandum maupun yang lainnya. ${ }^{14}$

Ada beberapa bahan khamar yang disebutkan dalam hadits, diantaranya:

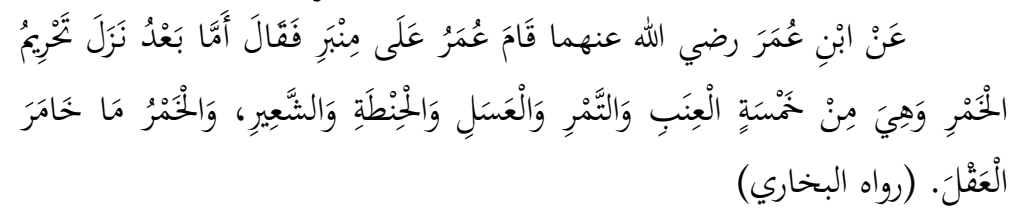

"Dari Ibnu Umar ra: 'Umar pernah berdiri di atas mimbar, lalu berkhutbah: 'Amma ba'du, pengharaman khamar turun, dan ia dapat berasal dari lima bahan: anggur, tamr, madu, hintah, (jewawut), dan gandum. Khamar itu segala sesuatu yang dapat mengacaukan akal'," (HR. Bukhari).

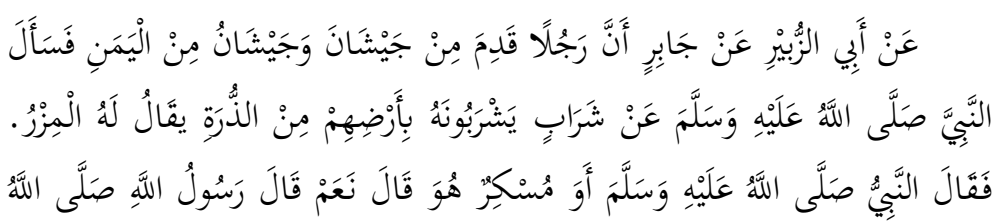

13 Muhammad Ali al-Shabuni, Rawāi' al-Bayān fì Tafsīr Āyāt Ahkām, (Beirut: Dar al-Qur`an al Karim, 1999), cet. I, jilid 1, h. 189.

14 Muhammad Ali al-Shabuni, Rawāi' al-Bayān fĩ Tafsīr Āyāt Ahkām, h. 196. 


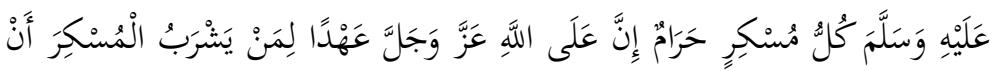

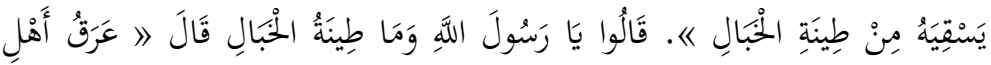

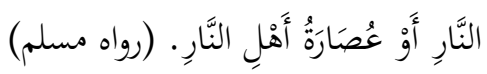

"Dari Abu al-Zubair, dan Jabir: 'Bahwasanya ada seorang laki-laki yang datang dari Jaisyan (sebuah daerah di Yaman). Lalu ia bertanya kepada Nabi Saw tentang minuman yang diminum orang-orang di negerinya yang terbuat dari jagung, yang disebut sebagai al-mizr. maka nabi Saw bersabda: 'Apakah ia termasuk minuman yang memabukkan?'. Ia menjawab: 'Ya, Rasulullah Saw bersabda: 'Segala sesuatu yang memabukkan adalah haram. Sesungguhnya Allah mempunyai perjanjian. Barang siapa yang meminum minuman yang memabukkan, Allah akan memberinya minum kelak dengan tīnat al-khabāl'. Mereka berkata: 'Wahai Rasulullah, apa itu ținat al-khabāl?.' Beliau bersabda: 'Keringat penduduk neraka atau kotoran penduduk neraka'," (HR. Muslim).

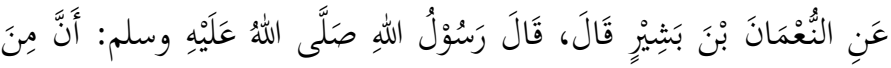

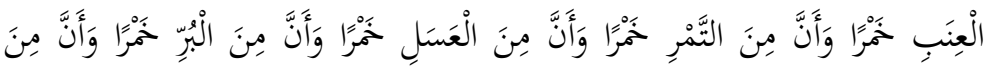

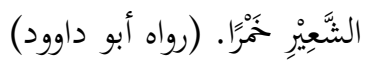

"Dari al-Nu'man bin Basyir, ia berkata: telah bersabda Rasulullah Saw: 'Sesungguhnya pada anggur, tamr, madu, burr (sejenis gandum), gandum terdapat khamar'," (HR. Abu Dawud).

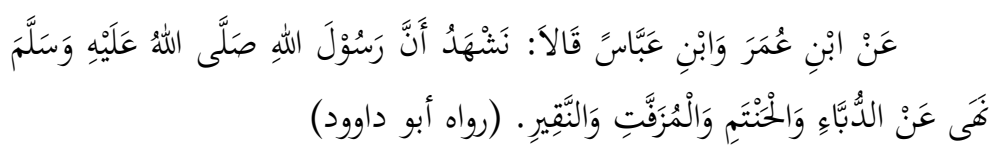

"Dari Ibnu Umar dan Ibnu 'Abbas, mereka berdua berkata: "Kami bersaksi bahwa Rasulullah Saw melarang membuat dan mengkonsumsi nabiż) dari dubbā', hantam, muzaffat, dan naqī," (HR. Abu Dawud).

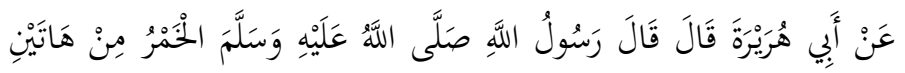

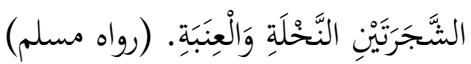




\section{Zainuddin Abdullah}

"Dari Abu Hurairah ia berkata: 'Telah bersabda Rasulullah Saw': 'Khamar itu berasal dari dua jenis pohon ini: kurma dan anggur'," (HR. Muslim).

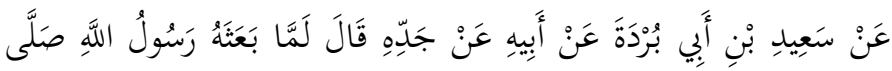

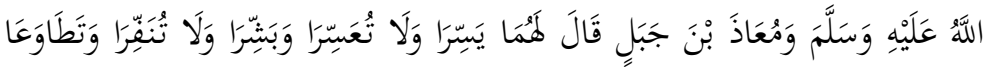

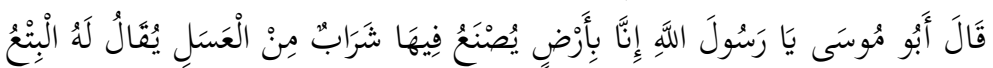

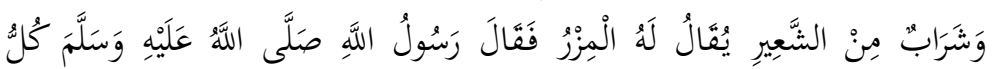

$$
\text { مُسنكِِرٍ حَرَامٌ. (رواه البخاري) }
$$

"Dari Sa'id bin Abi Burdah, dari ayahnya, dari kakeknya, ia berkata: Ketika Rasulullah Saw mengutusnya dan Mu'adz bin Jabal ke Yaman, beliau bersabda keduanya: 'Permudahlah dan jangan kalian persulit. Berikanlah khabar gembira dan jangan membuat orang lari (dari dakwah). Dan bahu membahulah kalian. Abu Musa berkata: 'Wahai Rasulullah, sesungguhnya kami berada di negeri yang dibuat padanya minuman dari madu yang disebut al-bit'u dan minuman yang terbuat dari gandum yang disebut al-mizr'. Maka Rasulullah Saw bersabda: 'Setiap yang memabukkan itu haram" (HR Bukhari).

Menurut hemat penulis bahwa khamar dengan beberapa bahan yang disebutkan dalam riwayat-riwayat di atas bukanlah sebagai pembatas tetapi lebih kepada penyebutan kasus-kasus atau bentuk-bentuk khamar yang ada pada waktu itu. Karena kemampuan pengetahuan dan teknologi yang mereka temukan dalam pembuatan sesuatu yang bisa memabukkan pada waktu itu terbatas pada apa yang sudah disebutkan di atas. AlBaghawi berkata setelah menyebutkan hadits Umar bin al-Khathab ra di atas:

في هذه الأحاديث دليل واضح على بطلان قول من زعم أن الخمر إنما

هي من عصير العنب أو رطب البيء الشديد منه وعلى فساد قول من زعم أن لا

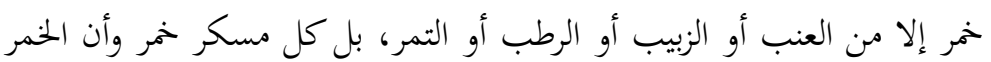

ما يخامر العقل. وقد روي عن الشعب عن النعمان بن بشير قال: قال رسول الله 


$$
\begin{aligned}
& \text { صلى الله عليه وسلم: (إن من العنب خمرا وإن من السل خمرا وإن من البر خمرا } \\
& \text { وإن من الشعير خمرا)، فهذا تصريح بأن الخمر قد تكون من غير العنب والتمر، }
\end{aligned}
$$

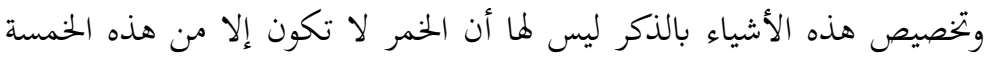

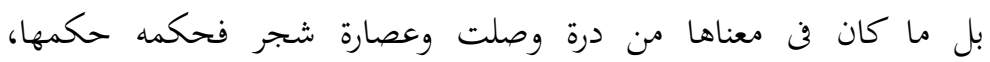

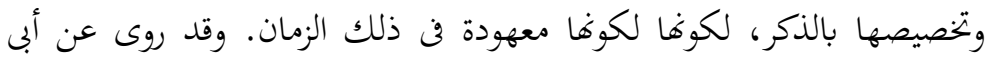

$$
\begin{aligned}
& \text { هريرة قال: قال رسول الله صلى الله عليه وسلم: (الخمر من هاتين الشجرتين: }
\end{aligned}
$$

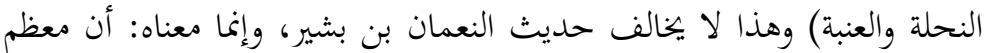

$$
\begin{aligned}
& \text { الخمر يكون منها، وهو الأغلب على عادة الناس فيما يتخدونه من الخمور. }
\end{aligned}
$$

"Pada hadits-hadits ini terdapat dalil yang jelas atas batilnya pendapat orang yang mengatakan bahwa khamar itu hanya terbatas pada perasan anggur atau ruthab mentah yang masih keras. Juga menunjukkan rusaknya pendapat orang yang mengatakan bahwa tidak ada khamar selain yang berasal dari anggur, kismis, atau tamr. Bahkan, segala sesuatu yang memabukkan adalah khamar. Dan sesungguhnya khamar adalah apa-apa yang mencampuri/mengacaukan akal. Telah diriwayatkan dari al-Sya'bi, dari al-Nu'man bin Basyir, ia berkata: telah bersabda Rasulullah Saw: 'Sesungguhnya pada anggur, madu, burr (sejenis gandum) dan gandum terdapat khamar.' Maka jelaslah bahwa khamar dapat juga berasal dari selain anggur dan tamr. Pengkhususan terdapat hal-hal itu dengan penyebutnya, bukanlah mengartikan tidak ada khamar kecuali dari lima jenis ini. Bahkan setiap hal yang tercakup maknanya dari jagung, gandum hitam, dan sari-sari pohon (nira), maka hukumnya sama dengan hukum khamar (jika ia memabukkan). Pengkhususan dengan penyebutannya adalah karena kenyataannya khamar hanya dibuat dari lima jenis pada zaman itu. Telah diriwayatkan dari Abu Hurairah, ia berkata: 'Telah bersabda Rasulullah Saw: 'Khamar itu berasal dari dua jenis pohon ini: kurma dan anggur'. Hadits ini tidak bertentangan dengan hadits alNu'man bin Basyir. Hanya saja maknanya adalah: Sesungguhnya kebanyakan khamar berasal darinya, dan kebanyakan orang memang biasa membuat khamar darinya'." 


\section{Zainuddin Abdullah}

\section{Tahapan (Gradualitas) Pengharaman Khamar Dalam Al-Qur`an}

Meskipun umat Islam bersepakat bahwa ketetapan hukum final dari khamar adalah haram, sebenarnya ketetapan hukum itu adalah melalui beberapa tahapan. Proses pengharaman khamar secara bertahap ini menunjukkan bahwa al-Qur'an menempuh cara yang bijaksana dalam proses pengharaman khamar. Adapun tahapan pensyariatannya adalah sebagai berikut:

a. Tahap pertama Allah membahas klasifikasi minuman, bahwa ada yang baik dan ada yang memabukkan. Hal ini Allah dijelaskan di dalam firman-Nya:

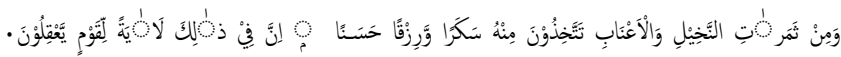

(67/16:النحل:(6)

"Dan dari buah korma dan anggur, kamu buat minuman yang memabukkan dan rezeki yang baik. Sesungguhnya pada yang demikian itu benar-benar terdapat tanda (kebesaran Allah) bagi orang yang memikirkan," (QS. al-Naḥl [16]: 67).

Dari ayat tersebut, dapat dilihat dengan jelas bahwa Allah membagi minuman itu ada yang bersifat baik dan ada pula yang bersifat memabukkan. Pada saat Allah menurunkan ayat ini, khamar memang belum diharamkan oleh karena itu Allah sama sekali tidak menyinggung tentang dosa dan juga keharaman bagi peminum khamar sehingga masyarakat pada saat itu masih banyak yang memfermentasikan air dari buah-buahan untuk dijadikan khamar kemudian meminumnya. Dengan kata lain pada saat awal Islam yang dibawah oleh Nabi Muhammad Saw datang khamar bukanlah minuman yang haram untuk dikonsumsi.

Mudjab Mahalli dalam bukunya Asbabun Nuzul (Studi Pendalaman Al-Qur'an) menyebutkan bahwa ayat tersebut adalah ayat pertama yang menyinggung tentang khamar. Ayat itu turun ketika Nabi Muhammad Saw pertama kali memasuki kota Madinah. Pada saat itu beliau mendapati penduduk 
Madinah gemar meminum arak (minuman yang memabukkan) dan makan dari hasil perjudian". ${ }^{15}$

b. Allah mengkomparasikan kandungan khamar, menyampaikan fakta, bahwa khamar mengandung manfaat dan mafsadat, akan tetapi mafsadatnya lebih besar daripada manfaatnya, hal ini bisa dilihat di dalam al-Qur`an:

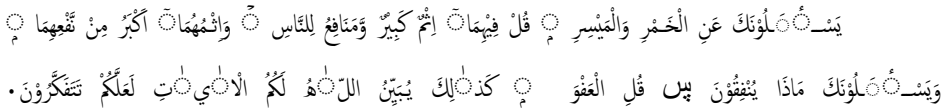

(219/2:البقرة: (20)

"Mereka bertanya kepadamu tentang khamar dan judi. Katakanlah: 'Pada keduanya itu terdapat dosa besar dan beberapa manfaat bagi manusia, tetapi dosa keduanya lebih besar dari manfaatnya. Dan mereka bertanya kepadamu apa yang mereka nafkahkan. Katakanlah: 'Yang lebih dari keperluan'. Demikianlah Allah menerangkan ayat-ayat-Nya kepadamu supaya kamu berpikir'," (QS. al-Baqarah [2]: 219).

Dari ayat tersebut, dapat diambil pengertian bahwa Allah membandingkan antara sisi positif dan sisi negatif dari khamar. Disebutkan bahwa dalam khamar itu terkandung dua aspek, yaitu dosa yang besar dan manfaat bagi manusia. Hal ini menolak argumen dari orang yang menyatakan bahwa khamar itu segala sesuatunya haram dan merugikan. Ketika ayat ini turun, sebagian masyarakat pada saat itu masih tetap meminumnya, dan sebagian yang lain menolaknya. Mereka meminum khamar karena manfaatnya, diantara adalah khamar itu merupakan jenis minuman yang sangat lezat pada masa itu, menghangatkan tubuh, dan manfaat lainnya sehingga karena belum ada pengharaman secara mutlak, mereka menikmati khamar itu.

Sedangkan إثم كبير yang terdapat di dalam khamar adalah sifat memabukkannya, nah di sini Allah belum sampai pada tahap pengharaman khamar, Allah

15 A. Mudjab Mahalli, Asbabun Nuzul (Studi Pendalaman AlQur an), (Jakarta: PT. Raja Grafindo Persada, t.th.).

154| Al Amin: Jurnal Kajian Ilmu dan Budaya Islam, Volume 1, No 2, 2018 


\section{Zainuddin Abdullah}

masih membandingkan antara aspek positif dan negatif yang terkandung di dalam khamar. Tetapi kalimat (وإثهما أكبر من نغعهم) itu menunjukkan dengan jelas bahwa aspek negatif yang ada pada khamar itu lebih dominan daripada aspek positifnya.

c. Tahapan ketiga Allah Swt masih belum mengharamkan khamar secara tegas tetapi baru membatasi mengkonsumsinya (membatasi frekuensi minum khamar) agar tidak kecanduan. Dalam hal ini Allah Swt, berfirman dalam al-Qur`an:

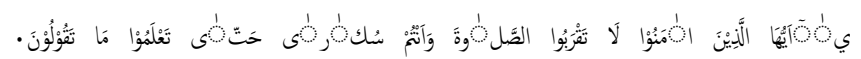

"Hai orang-orang yang beriman, janganlah kamu shalat, sedang kamu dalam keadaan mabuk, sehingga kamu mengerti apa yang kamu ucapkan," (QS. al-Nisā' [4]: 43).

Dari ayat tersebut dapat diketahui bahwasanya Allah Swt, belum secara tegas mengharamkan khamar. Tetapi sudah membatasi pengonsumsiannya dengan larangan mendekati (melakukan) shalat dalam keadaan mabuk (karena pengaruh minum khamar)

d. Tahap keempat barulah Allah Swt, mengharamkan khamar secara tegas.

Inilah hukum final dari khamar, yaitu haram secara tegas dan mutlak. Firman Allah Swt:

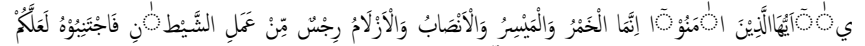

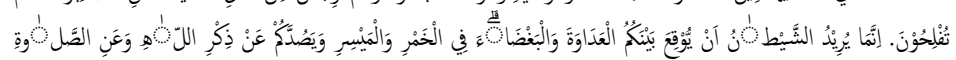

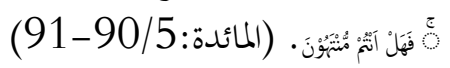

"Hai orang-orang yang beriman, sesungguhnya (meminum khamar, berjudi, (berkorban untuk) berhala, mengundi nasib dengan panah, adalah perbuatan keji termasuk perbuatan setan. Maka jauhilah perbuatanperbuatan itu agar kamu mendapat keberuntungan. Sesungguhnya setan itu bermaksud hendak menimbulkan permusuhan dan kebencian diantara kamu lantaran (meminum) khamar dan berjudi itu, dan menghalangi kamu dari mengingat Allah dan 
sembahyang; maka berhentilah kamu (dari mengerjakan pekerjaan itu)," (QS. al-Māidah [5]: 9091).

Dari ayat tersebut, akhirnya Allah Swt mengharamkan khamar secara mutlak dan tegas. Allah Swt telah menjelaskan bahwa khamar itu merupakan hal kotor dan dianggap menjijikkan yang رجس harus dijauhi. Hal itu bisa diketahui dari kalimat dan kata فن datimat larangan yang tidak disertai dengan pembatasan (muqayyid), artinya sudah dimutlaqkan keharamannya.

Jadi kesimpulannya, khamar itu hukumnya haram untuk diminum, meskipun syariat keharamannya itu tidak sertamerta haram, tetapi menurut penjelasan di atas, hukum final dari khamar itu menunjukkan keharamannya. Allah tidak menetapkan hukum secara bertahap hanya untuk kepentingannya sendiri, tetapi Allah mempunyai maksud mulia, yaitu agar mudah dipahami dan memudahkan dalam pengerjaannya oleh manusia. Dalam hal ini digunakan prinsip meniadakan kesulitan (عدم الحرج).

Aturan larangan (pengharaman) minuman keras (khamar) berlaku untuk seluruh umat Islam serta tidak ada pengecualian untuk individu tertentu. Dalam hal mengonsumsinya, terlepas apakah si peminum tersebut mabuk atau tidak, khamar tetap haram.

Beberapa hadis Nabi Saw juga secara tegas telah menetapkan keharaman khamar secara mutlak, diantaranya:

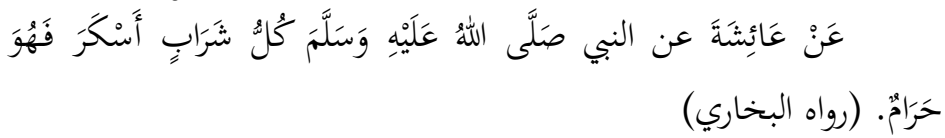

"Dari Aisyah ra dari Nabi saw, beliau telah bersabda 'Telah menceritakan kepada kami Ali bin Abdillah, dia berkata telah menceritakan kepada kami Sufyan, dia berkata telah menceritakan kepada kami al-Zuhri, dari Abu Salamah, dari Aisyah, dari Nabi Saw 


\section{Zainuddin Abdullah}

dia berkata: 'Semua minuman yang memabukkan itu adalah haram'," (HR. Bukhari).

Dari riwayat lain juga diterangkan keharamannya:

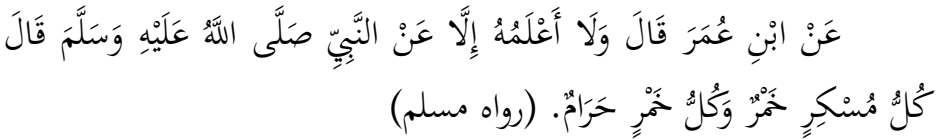

"Dari Ibnu Umar ra, dia berkata: 'Aku tidak mengetahui perkara ini kecuali dari Nabi Saw, beliau bersabda: 'semua yang memabukkan adalah khamar, dan semua khamar itu haram," (HR. Muslim).

Dari beberapa ayat dan hadits yang dipaparkan di atas maka dapat dipahami bahwa khamar meliputi semua jenis makanan dan minuman yang memabukkan, sedangkan 'illat keharamannya adalah: Pertama, ditegaskan bahwa khamar mengandung dosa besar. Kedua, karena khamar mengandung dosa (mafsadat), sedangkan dosa itu haram, tentu mengandung pula siksa ('iqāb) dan dosa (żanb). Ketiga, penegasan bahwa dosa (mafsadat) khamar lebih besar dari manfaatnya. Keempat, khamar termasuk seburuk-buruk dosa dan bahaya yang mengancam kehidupan pribadi dan masyarakat. Kelima, khamar dapat menimbulkan kebencian dan permusuhan dan permusuhan bahkan pembunuhan di tengah masyarakat. Karena itu Allah mengharamkannya dan menegaskan berulang kali dengan sejumlah isyarat mengenai hal itu. Keenam, ditegaskan bahwa khamar adalah keji, kotor dan perbuatan setan.

\section{Ketetapan Pidana (Jināyah) yang berkaitan dengan Narkoba}

Berdasarkan berat ringannya hukuman atau pelanggaran yang dilakukan oleh seseorang maka hukum pidana Islam (jināyah atau jarīmah) dibagi menjadi tiga macam golongan, yaitu:

a. Tindak pidana hudūd, yang sering diartikan sebagai hukum atau ketetapan Allah Swt. Orang yang melakukan tindak pidana ini akan dikenai hukuman sesuai dengan yang telah ditetapkan oleh Allah Swt, tidak bisa ditambah atau dikurangi. 
Hukuman yang diberikan kepada para pelaku tindak pidana hudūd merupakan hak Allah Swt, yang tidak bisa dihapuskan, baik oleh perseorangan yang menjadi korban tindak pidana itu sendiri maupun oleh masyarakat yang diwakili lembaga negara.

Dalam hukum Islam dikenal tujuh macam tindak pidana hudūd, yaitu: zina, qażaf (menuduh orang berbuat zina), meminum minuman keras, mencuri, hirābah (orang yang memerangi Allah Swt, dan rasulNya), murtad, dan orang yang memberontak terhadap penguasa yang sah (bughāt).

b. Tindak pidana qiṣa ș dan diyat (ganti rugi). Tindakan pidana ini berkenaan dengan kejahatan terhadap orang, seperti membunuh dan menganiaya, bagi pelaku tindak pidana ini akan dikenai hukuman qiṣass atau diat dari individu yang menjadi korban. Kadar jumlah hukuman yang diberikan ditentukan oleh sang korban, namun tidak memiliki aturan batasan minimal atau maksimal.

Adapun tindak pidana qiṣass dan diyat ini terbagi dalam lima macam, yakni: pembunuhan yang disengaja, pembunuhan yang menyerupai disengaja, pembunuhan tersalah, penganiayaan disengaja, penganiayaan yang tersalah. Penganiayaan yang dimaksud di sini adalah perbuatan yang tidak sampai menghilangkan jiwa sang korban, seperti melukai, memotong, merusak dll.

c. Tindak pidana ta'zìr. Berupa kejahatan yang tidak termasuk dalam hudūd dan qiṣass-diyat, karena bentuk hukumannya diserahkan kepada kebijakan hakim. Istilah ta'zìr ini bermakna memberikan pendidikan (pendisiplinan). Maksudnya adalah memberikan hukuman yang bertujuan mengoreksi atau merehabilitasi pelaku kejahatan. ${ }^{16}$

Hukum Islam tidak menentukan macam-macam hukuman untuk tiap-tiap tindak pidana ta'zirr, tetapi hanya menyebutkan sekumpulan hukuman, dari yang paling ringan sampai yang paling berat ( $\mathrm{min}$ alnuṣhi ilà al-haddi). Dalam hal ini, hakim diberi kebebasan untuk memilih hukuman-hukuman yang

16 Hanafi, Asas-asas Hukum Pidana Islam, (Jakarta: Bulan Bintang, 1993), h. 7-8.

158| Al Amin:Jurnal Kajian Ilmu dan Budaya Islam, Volume 1, No 2, 2018 


\section{Zainuddin Abdullah}

sesuai dengan macam tindak pidana ta'zir serta keadaan si pelaku. Singkatnya, hukuman-hukuman tindak pidana ta'zir tidak mempunyai batasan tertentu.

Jenis tindak pidana ta'zìr tidak ditentukan banyaknya, seperti halnya tindak pidana hudūd dan qișass yang sudah ditentukan jumlah dan jenisnya. Hukum Islam sendiri hanya menentukan sebagian tindak pidana ta'zir, seperti riba, mengkhianati janji, memaki orang, dan menyuap.

Adapun sebagian besar dari tindak pidana ta'zir diserahkan kepada penguasa untuk menentukannya. Meski demikian, hukum Islam tidak memberikan wewenang kepada penguasa untuk dapat menentukan tindak pidana dengan sekehendak hati, tetapi harus sesuai dengan kepentingan masyarakat dan tidak boleh berlawanan dengan ketentuan serta prinsip-prinsip umum hukum Islam.

\section{Ketetapan Pidana (Jināyah) yang berkaitan dengan Narkoba}

Tujuan disyariatkannya hukum Islam adalah untuk mewujudkan dan memelihara kemaslahatan manusia yang ditekankan pada pemeliharaan lima sasaran pokok, yaitu agama, jiwa, akal, kehormatan dan keturunan, serta harta. Lima hal pokok ini wajib diwujudkan dan dipelihara jika seseorang menghendaki kehidupan yang berbahagia di dunia dan di hari kemudian, seperti ungkapannya dalam kitab al-Muwāfaqāt:

$$
\text { والدنيا معا. }
$$

"Sesungguhnya syariat itu ditetapkan bertujuan untuk tegaknya (mewujudkan) kemaslahatan manusia di dunia dan akhirat".

Ungkapan al-Syatibi "Hukum-hukum diundangkan untuk kemaslahatan hamba” (الأحكام الشرعية لمصالخ العباد-17 menegaskan bahwa doktrin maqāṣid al-syarīah adalah satu, yaitu mașlahah atau kebaikan dan kesejahteraan

17 al-Syatibi, al-Muwāfaqāt fì 'Ușūl al-Syarī'ah, (Kairo: Mustafa Muhammad, t. th.), jilid. II, h. 2-3. 
umat manusia baik di dunia maupun di akhirat. Segala upaya untuk mewujudkan dan memelihara lima pokok tadi sebagai isi dari maqāsid al-syarīah merupakan amalan saleh yang harus dilakukan oleh umat Islam. Sebaliknya, tindakan yang bisa mengancam keselamatan salah satu dari pokok tersebut dianggap sebagai tindakan kejahatan dan atau pelanggaran yang dilarang.

Dengan demikian jelaslah bahwa, tindakan kejahatan dapat dikategorikan ke dalam lima kelompok, yaitu kejahatan terhadap agama, kejahatan terhadap jiwa atau diri, kejahatan terhadap akal, kejahatan terhadap kehormatan dan keturunan, kejahatan terhadap harta benda. Masing-masing kejahatan itu diuraikan secara panjang lebar dalam literatur-literatur fikih dalam berbagai mazhab.

Kejahatan-kejahatan besar terhadap lima pokok ini diatur dalam bab jināyat. Jināyah atau jarīmah, yaitu tindak pidana di dalam hukum Islam berupa laranganlarangan syara' yang diancam oleh Allah dengan hukuman hadd atau ta'zir. Hukuman hadd adalah hukuman yang ditetapkan melalui wahyu yang merupakan hak Allah sebagai syari'. Hukuman ta'zir adalah hukuman yang tidak ada nasnya, dan ditetapkan berdasarkan pertimbangan hakim ( $q \bar{a} d i)$.

Berkenan dengan tindakan kejahatan yang berkaitan dengan narkoba atau khamar, penulis membagi bentuk hukuman (sanksi) menjadi dua bagian yaitu:

a. Sanksi hukum bagi pengonsumsi atau pecandu

Sanksi hukum yang diberlakukan kepada peminum/pengonsumsi khamar adalah hadd, yaitu didera (jilid) sebanyak 40 kali. Hal ini didasarkan atas hadits nabi Saw:

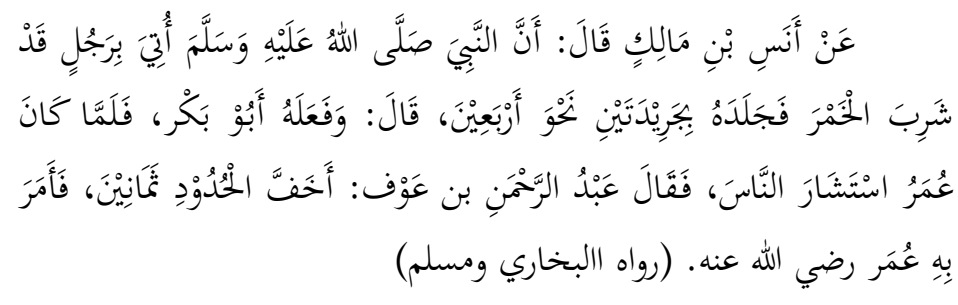

"Diriwayatkan dari Anas bin Malik ra, sesungguhnya Nabi Saw kedatangan seorang laki-laki 


\section{Zainuddin Abdullah}

yang telah meminum khamar kemudian Nabi Saw, menjilidnya dengan dua pelepah kurma sebanyak empat puluh kali. Anas berkata: dan Abu Bakar juga melakukannya (empat puluh kali jilid). Ketika Umar menemui peminum khamar, maka Abdurrahman bin 'Auf berkata: seringan-ringannya hudūd (batas hukuman meminum khamar) adalah delapan puluh kali, kemudian Umar memerintahkan (had meminum khamar) sebanyak delapan puluh kali." (HR. Bukhari dan Muslim).

Dalam hal mengeksekusi hadd peminum khamar para sahabat menderanya dengan menggunakan pelepah kurma, sebagaimana dalam diriwayatkan dalam hadits:

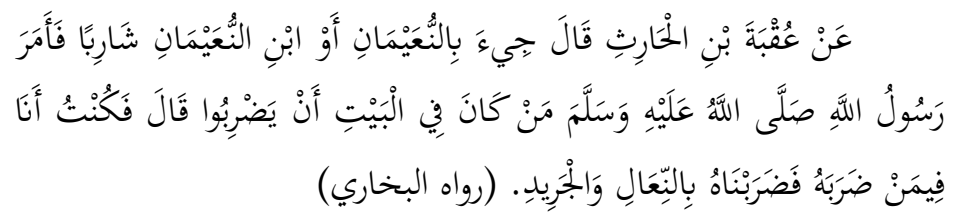

"Dari Uqbah bin Harist ra, katanya, telah didatangkan Nu'aiman atau Ibnu Nu'aimah, karena itu minum yang memabukkan, maka Rasulullah Saw, memerintahkan kepada orang yang di dalam rumah supaya memukulnya, maka Uqbah saja juga diantara orang-orang yang memukulnya lalu ia dipukul dengan terompah dan pelepah kurma," (HR. Bukhari).

Jelaslah bahwa hukuman yang disyariatkan terhadap peminum khamar adalah pukulan yang dimaksudkan untuk menghinakan si peminum, menghardiknya dan membuat orang-orang menjauhi perbuatan itu. Sedangkan pukulan sebanyak 40 atau 80 kali adalah ijtihad dari para khalifah. Abu Bakar memilih 40 kali, sedangkan Umar 80 kali berdasarkan kesepakatan Abdurrahman bin Auf yang menyerupakan dengan hadd menuduh wanita-wanita muhșanāt (yang memelihara diri).

Sedangkan jika yang bersangkutan berulang kali mengonsumsi khamar maka hukumannya ditingkatkan menjadi hukum mati. Hal ini didasarkan pada hadits nabi berikut ini: 


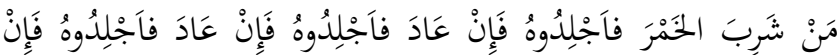 \\ عَادَ فَاَفتْتُلُوهُ.}

"Barangsiapa yang meminum khamar, hendaklah kamu mencambuknya, jika diulangi, hendaklah kamu cambuk. Jika ia masih mengulanginya, hendaklah kamu cambuk, jika pada keempat kalinya ia masih juga mengulangi, maka bunuhlah ia."

Dari hadits di atas jika dicermati, bahwa peminum khamar yang mudaratnya yang ditimbulkannya hanya sebatas dirinya saja, keempat kalinya ia harus dihukum mati. Tentunya yang lebih dari itu, yaitu bagi para pedagang atau pemasok yang sudah jelasjelas menimbulkan mudarat lebih luas tidak hanya menimpa perorangan, lebih layak mendapat vonis mati daripada peminum khamar.

b. Sanksi hukum bagi pengedar narkoba

Syariat Islam tidak hanya menjatuhkan hukuman atas penggunaan barang memabukkan semata, namun seluruh pihak yang terlibat dalam kasus penyalahgunaan juga terkena sanksi hukum. Abu Daud meriwayatkan dalam Sunannya dari Ibnu Umar ia berkata, Rasulullah Saw bersabda:

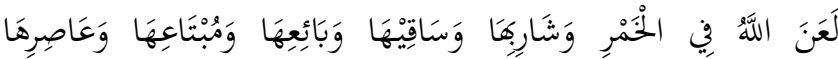

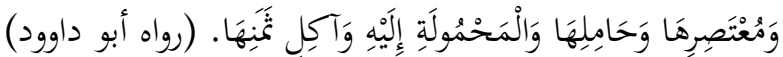

"Allah melaknat pemabuk khamar, penuang, penjual, pembeli, pemeras anggur, yang meminta diperaskan, yang membawa dan yang dibawakan," (HR. Abu Dawud).

Kemudian apakah sanksi (hukuman) yang tepat untuk para pengedar pembuat, pengedar dan yang membuat peredaran narkoba dalam pandangan Islam. Menurut hemat penulis tergantung bagaimana kita melihat pelakunya.

Sebelum masuk kepada bagaimana hukuman yang tepat dalam Islam, terlebih dahulu penulis akan menyampaikan bagaimana sanksi menurut hukum positif di Indonesia bagi pengedar narkoba. 


\section{Zainuddin Abdullah}

Seperti telah diketahui bahwa kejahatan yang dilakukan oleh pengedar narkoba merupakan kejahatan yang luar biasa (extra ordinary crime) di mana kejahatan tersebut merupakan kejahatan transnasional yang terorganisir secara rapi yang dampaknya luar biasa, luas dan sporadis secara sistemik.

Di Indonesia, tindak pidana yang tergolong sebagai tindak pidana luar biasa (extraordinary crime) seperti tindak pidana terorisme, narkotika, korupsi, maupun illegal logging pantas dijatuhi pidana mati. Bukan hanya karena modus operandi tindak pidana tersebut yang sangat terorganisir, namun ekses negatif yang meluas dan sistematik bagi khalayak, menjadi titik tekan yang paling dirasakan masyarakat. Maka sebagai langkah yuridis yang menentukan eksistensi keberlakuan pidana hukuman mati di Indonesia, maka keluarlah putusan MK Nomor 23/PUUV/2007. ${ }^{18}$

Dalam undang-undang Nomor 35 Tahun 2009 tentang Narkotika telah memuat pidana mati. Bahwa ancaman pidana mati bagi pengedar diatur dalam Pasal 114 ayat (2) dan pasal 119 ayat (2). Adapun bunyi pasal tersebut adalah: Pasal 114 ayat (2): dijelaskan bahwa dalam hal perbuatan menawarkan untuk dijual, menjual, membeli, menjadi perantara dalam jual beli, menukar, menyerahkan, atau menerima Narkotika Golongan I sebagaimana dimaksud pada ayat (1) yang dalam bentuk tanaman beratnya melebihi 1 (satu) kilogram atau melebihi 5 (lima) batang pohon atau dalam bentuk bukan tanaman beratnya 5 (lima) gram, pelaku dipidana dengan pidana mati, pidana seumur hidup, atau pidana penjara paling singkat 6 (enam) tahun dan paling lama 20 (dua puluh) tahun dan dipidana denda maksimum sebagaimana dimaksud pada ayat (1) ditambah $1 / 3$ (sepertiga).

18 Muhammad Rustamaji, Menyoal Eksistensi Pidana Hukuman Mati di Indonesia, http://rustamaji 1103, wordpress.com/2015/03/25/menyoal-eksistensi-pidana-hukumanmati-diindonesia/diunduh pada tanggal 25 maret 2015 pukul 15.00 WIB 
Pasal 119 ayat (2): dalam hal perbuatan menawarkan untuk dijual, menjual, membeli, menerima, menjadi perantara dalam jual beli, menukar, atau menyerahkan Narkotika Golongan II sebagaimana dimaksud pada ayat (1) beratnya melebihi 5 (lima) gram, pelaku dipidana dengan pidana mati, pidana penjara seumur hidup, atau pidana penjara paling singkat 5 (lima) tahun dan paling lama 20 (dua puluh) tahun dan pidana denda maksimum sebagaimana dimaksud pada ayat (1) ditambah $1 / 3$ (sepertiga). ${ }^{19}$

Dalam pasal 114 ayat 2 tersebut menjelaskan bahwa sanksi tindak pidana narkotika adalah pidana mati, pidana penjara seumur hidup, atau pidana penjara paling singkat 6 (enam) tahun dan paling lima 20 (dua puluh) tahun dan pidana denda maksimum sebagaimana dimaksud pada ayat (1) ditambah 1/3 (sepertiga). Sedangkan dalam pasal 119 ayat 2 sanksinya adalah pidana mati, pidana penjara seumur hidup, atau pidana paling singkat 5 (lima) tahun dan paling lama 20 (dua puluh) tahun dan pidana denda maksimum sebagaimana dimaksud pada ayat (1) ditambah 1/3 (sepertiga). Yakni bahwa sanksi pidana tersebut sangat dinamis yaitu adanya sanksi minimum khusus (paling singkat 6 (enam) tahun pada pasal 114 ayat 2 dan paling singkat 5 (lima) tahun pada pasal 119 ayat (2) dan juga maksimum khusus (pidana mati). Dalam pasal tersebut juga terdapat kata 'atau' dan kata 'dan' yakni bahwa pasal tersebut dapat dijatuhkan secara kumulatif atau alternatif yang diimplikasikan dengan kata 'dan' maupun kata 'atau'.

Dalam hukum Islam, bahwa kategori kejahatan luar biasa adalah jarimah hirābah. Penetapan hirābah sebagai jarimah yang secara formal mengakibatkan ekses yang luas pada masyarakat didasarkan pada surat al-Māidah [5]: 33:

19 Undang-Undang RI Nomor 35 Tahun 2009 tentang Narkotika dan Penjelasannya, (Bandung: Citra Umbara, 2010), h. 50 .

164| Al Amin: Jurnal Kajian Ilmu dan Budaya Islam, Volume 1, No 2, 2018 


\section{Zainuddin Abdullah}

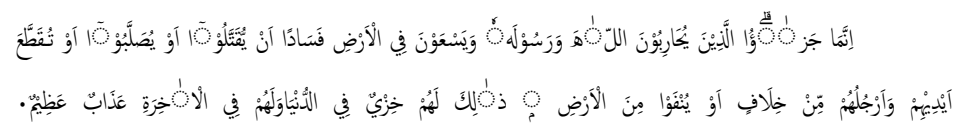

(المائدة:33/5)

"Hukuman bagi orang-orang yang memerangi Allah dan Rasul-Nya dan membuat kerusakan di muka bumi, hanyalah dibunuh atau disalib, atau dipotong tangan dan kaki mereka secara silang atau diasingkan dari tempat kediamannya. Yang demikian itu kehinaan bagi mereka di dunia, dan di akhirat mereka mendapat azab yang besar," (QS. al-Māidah [5]: 33).

Selanjutnya, apakah para pengedar narkoba itu sama dengan kejahatan setingkat hirabah. Jika melalui kajian yang akurat ternyata disimpulkan bisa disamakan, maka berarti dia bagian dari bentuk hirabah yang penerapan sanksi hukumannya adalah hadd yaitu dibunuh, disalib, atau dipotong tangan dan kakinya secara bersilang dan seterusnya.

Jika kategori hirabah itu 'ilat hukumnya adalah يسعون في الأرض فسادا (berdampak luar biasa, luas dan sporadis serta sistematik kerusakannya), tampaknya pengedar narkoba dengan skala besar bisa dikategorikan sebagai hirabah, karena sama-sama menyebarkan kerusakan secara luas dan melawan hukum yang berlaku, memerangi Allah, menentang ajaran Rasulullah, dan dapat merusak tatanan negara.

Iman al-Suyuti dalam tafsirnya mengatakan bahwa yang dimaksud menyebarkan kerusakan di muka bumi itu modusnya bisa berbentuk perzinaan, pencurian, pembunuhan, merusak harta dan keturunan. ${ }^{20}$

Dengan demikian maka pengedar narkoba bisa dikategorikan sebagai bentuk hirabah yang sangat bertentangan dengan maqāsid al-syarīah khususnya al-ḍaüriyyah al-khams dan karenanya maka sudah layak dihukum mati.

20 Abdurahman bin Abu Bakr al-Suyuthi, al-Dur al-Manśūr fì al-Tafsīr bi al-Ma šur, (Kairo: Dar Hijr, 2003), juz V, h. 209. 
Diberlakukannya hukuman mati kepada yang bersangkutan bukan melalui ketetapan ta'zir tetapi melalui ketetapan hadd sebagai dinyatakan dalam surat al-Māidah ayat tiga.

\section{Kesimpulan}

Dari paparan di atas dapat disimpulkan bahwa:

1. Pada masa awal Islam makna khamar terbatas pada jenis minuman yang memabukkan yang terbuat dari perasaan anggur, korma, gandum dan sejenisnya. Namun demikian tidak berarti bahwa khamar terbatas pada apa yang muncul pada masa awal Islam itu tetapi lebih kepada bahwa bentuk yang ditemukan pada waktu itu masih sangat terbatas. Oleh karena itu, makna khamar selanjutnya mengalami perkembangan baik dari jenis, nama dan bahayanya sesuai dengan perkembangan jamannya.

2. Sanksi hukum yang berkaitan dengan penyalahgunaan Narkoba adalah ditetapkan berdasarkan hukum had (hudūd). Pengonsumsinya didera sebanyak 40 kali dan sebagian sahabat menambahnya dengan 80 kali. Sedangkan jika berulang-ulang (pecandu) sampai melakukan 4 kali maka bisa dikenakan hukuman mati.

3. Dalam hukuman Islam, bagi pengedar narkoba dengan skala tertentu bisa dikategorikan tindak pidana hirābah, kejahatan luar biasa besar (ekstra ordinary crime) dan karenanya diancam dengan hukuman hudūd sampai pada hukuman mati. Hal ini sesuai dengan semangat maqāsid al-syariah khususnya menyangkut al-darūriyyah alkhams. 


\section{Zainuddin Abdullah}

\section{DAFTAR PUSTAKA}

A. Mudjab Mahalli, Asbabun Nuzul (Studi Pendalaman AlQur`an), Jakarta: PT Raja Grafindo Persada, 2002.

Abdullah bin Abdurrahman bin Shalih Ali Bassam, Taisīr alĀlam Syarh 'Umdah al-Hikam, Maktabah al-Syamilah, Juz 2.

Abdurrahman bin Abu Bakr al-Suyuthi, al-Durr al-Mansīur fĩ al-Tafsìr bi al-Ma ṡür, Kairo: Dar Hijr, 2003, (Maktabah Syamilah).

Ahmad Syauqi Al-Fanjuri, Nilai Kesehatan Dalam Syariat Islam, Jakarta: Bumi Aksara, 1999, cet II.

Al-Syatiby, al-Muwāfaqāt fĩ Ușūl al-Syarīah, Kairo: Mustafa Muhammad, t.th., jilid II.

Deputi Bidang Pencegahan Badan Narkotika Nasional Republik Indonesia, Mahasiswa dan Bahaya Narkotika, Jakarta: BNNRI, 2012.

Dirumuskan oleh tim kerja BNN, Mabes Polri, Depdagri dan BKKBN, Pedoman Pelaksanaan P4GN/Melalui Pesan serta Kepala Desa/Lurah Babinkamtibnas dan PLKB ditingkat Desa/Kelurahan, Jakarta: Badan Narkotika Nasional, 2007.

http://ww.merdeka.com/peristiwa/pengguna-narkoba-diindonesia-pada-2015-capai-58-juta-jiwa.html, diases pada hari Selasa pukul 23.00

Muhammad Ali al-Shabuni, Tafsīr Āyāt Ahkām, Beirut: Dar al-Qur`an al Karim, 1999, cet. 1, Jilid 1.

Muhammad Rustamaji, menyoal Eksistensi Pidana Hukuman Mati di Indonesia, http://rustamaji 1103, wordpress.com/2015/03/25/menyoal-eksistensipidana-hukuman-mati-diindonesia/diunduh pada tanggal 25 maret 2015 pukul 15.00 WIB.

Tim Perumus dari BNN RI, Mengenal Penyalahgunaan, Jakarta: Badan Narkotika, Nasional, 2007.

Tim Perumus dari BNN RI, Modul untuk Orangtua: Mencegah Lebih Baik daripada Mengobati, Jakarta: Badan Narkotika Nasional, 2007. 
Undang-Undang RI Nomor 35 Tahun 2009 tentang Narkotika dan Penjelasannya, Bandung: Citra Umbara, 2010.

Zainudin Ali, Hukum Pidana Islam, Jakarta: Sinar Grafika, 2007, cet. 1 . 


\section{Zainuddin Abdullah}

Al Amin: Jurnal Kajian Ilmu dan Budaya Islam, Volume 1, No 2, 2018 | 169 